MATEC Web of Conferences 22,05001 (2015)

DOI: $10.1051 /$ matec conf/ 20152205001

(C) Owned by the authors, published by EDP Sciences, 2015

\title{
Synthesis, Biological Evaluation and Molecular Docking Studies of Ferrocene Derivatives Coupling with N-heterocyclic on Human Breast Cancer
}

Yunlong Wu \& Zhiyi Yao*

School of Chemical and Environmental Engineering, Shanghai Institute of Technology, Shanghai, China

\begin{abstract}
A series of heterocyclic ferrocene derivatives (Fc1-Fc18) was designed and synthesized. The eight representative target compounds were evaluated for their antitumor activities against human breast cancer (MCF-7) cells using MTT assay. Compounds Fc3, Fc11, Fc12, and Fc17 inhibited MCF-7 cells at IC50 values of $39.2,44.2,48.3$, and $24.2(\mu \mathrm{mol} / \mathrm{L})$. In the eight heterocyclic ferrocene derivatives, results indicated that they had a pyridine group and produced ester which is more effective in inhibiting MCF-7 cells than that of amide-producing heterocyclic ferrocene derivatives without a pyridine group. Docking simulation was also performed to position compounds into the human enzyme aromatase (AR, CYP19) active site adequately to explain the probable reasons why the compounds have antitumor activities. The authors observed that compound Fc17, which had the highest affinity to the receptor, was stabilized by two respective hydrogen bonds with Thr310 and Ser314.
\end{abstract}

Keywords: ferrocene heterocyclic derivative; antitumor activity; MCF-7 cell; enzyme aromatase

\section{INTRODUCTION}

Since Pauson et al. [1, 2] discovered this metalorganic compound ferrocene in 1951, its derivatives have been extensively researched. The ferrocene derivatives exhibit good fat solubility through the cell membrane and combine with intracellular enzymes.[3] Since the 1980s, Kopf-Maier et al. [4, 5, 6]discovered that ferrocene derivatives have a inhibitory effect on malignant tumor cells proliferation. From 1980, the antitumor activity has been discovered in metalorganic compounds, including alkyl ferrocene, ferrocene alkyl azole, yokes of ferrocene biological macromolecule compounds, and ferrocene-modified cisplatin. [7]

The human breast cancer is a major public health problem. Seventy-five percent of breast cancers in postmenopausal women are estrogen-dependent [8]. Meanwhile, estrogens are principally produced by ovaries in premenopausal women and continue to be synthesized by non-ovarian tissues [9], such as the breast tissue in postmenopausal women [10]. Estrogens are biosynthesized from circulating androgens through an aromatization reaction of the steroidal A-ring, catalyzed by the enzyme aromatase (AR, CYP19). The inhibition of estrogen biosynthesis by the third-generation aromatase inhibitors exemestane, letrozole, and anastrozole is the frontline therapy for postmenopausal estrogen-dependent breast cancer [11, 12]. The enzyme has been the subject of intensely biochemical and biophysical investigations for the past 40 years [13].

In the current work, we used a newly refined aro-

*Corresponding author: yao99cn@sit.edu.cn matase-androstenedione complex structure (Figure 1; PDB code 3EQM [14]), which had overall quality and refinement parameter statistics for molecular docking to find a new aromatase inhibitor. We synthesized a series of ferrocene heterocyclic derivatives and evaluated the new compounds for their antitumor activities against human breast cancer MCF-7 cells in vitro. The objective was to explore the influence of ferrocene heterocyclic derivatives, which were modified by seven heterocycles $(\mathbf{1 b}-\mathbf{7 b})$ on tumor cell activity to identify better candidate compounds against the human breast cancer. Surflex-Dock was used to explain the probable reasons why the compounds have antitumor activities, wherein the small molecule ligands which were positioned in the active site of the target receptor where the original ligand ASD (4-ANDROSTENE-3-17-DIONE) was extracted. Then, the designed compounds were led into the cavity.

\section{EXPERIMENTAL SECTION}

\subsection{Materials and methods}

The melting points were recorded on a WPS-2A digital melting point apparatus and they were uncorrected. ${ }^{1} \mathrm{H}$ NMR and ${ }^{13} \mathrm{C}$ NMR spectra were recorded at 500 $\mathrm{MHz}$ on a Bruker Avance III 500 spectrometer with TMS as the internal standard. IR spectra were recorded on a Nicolet 6700 spectrometer $(\mathrm{KBr})$. The mass spectra were recorded on a Shimadzu 2020 spectrometer. The HR-MS spectra were recorded on a SolariX-70FT-MS Bruker spectrometer. All reagents were analytical grades. 


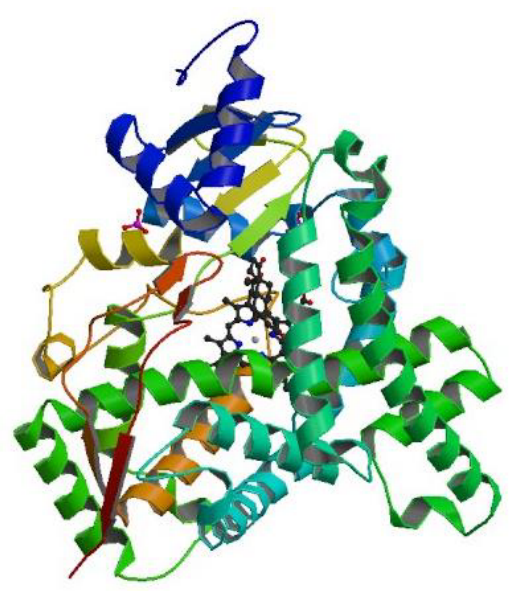

Figure 1. Biological assembly image for 3EQM

2.2 General method for the preparation of target compounds (Fc1-Fc18)

\subsubsection{Synthesis of $\mathbf{2 a - 4 a}$}

The synthesis of ferrocenylacetic acid (2a) was based on references [15] and [16], whereas the syntheses of ferrocene acyl propionic acid (3a) and ferrocene acyl butyric acid (4a) were based on reference [17].

\subsubsection{Synthesis of compounds Fc5, Fc6, Fc12 and Fc17}

Ferrocene carboxylic acid $(1.0 \mathrm{mmol}), \mathrm{EDCl}(206.0$ $\mathrm{mg}, 1.0 \mathrm{mmol})$, and DMAP $(12.2 \mathrm{mg}, 0.1 \mathrm{mmol})$ were dissolved in dichloromethane $(30.0 \mathrm{ml})$ and then stirred for $45 \mathrm{~min}$ in ice water. Then, $\mathbf{5 b}$ or $\mathbf{6 b}(2.0$ $\mathrm{mmol}$ or $4.0 \mathrm{mmol}$ ) was added to the solution, and the mixture was stirred for $24 \mathrm{~h}$. After reaction completion as monitored by thin-layer chromatography, the solution was washed with brine and extracted with dichloromethane. The organic phase was dried over anhydrous sodium sulfate, filtered, and concentrated in vacuo to obtain the crude product. The residue was purified by flash chromatography (silica gel and ethyl acetate/petroleum ether) to provide the target compounds.

Ferrocene formic acid-4-methyl pyridine (Fc5)

Mp:77.3-79.0 ${ }^{\circ} \mathrm{C} ;{ }^{1} \mathrm{H}$ NMR( $\left.\mathrm{CDCl}_{3}, 500 \mathrm{MHz}\right) \delta$ : $8.69(\mathrm{~s}, 2 \mathrm{H}) \quad, 7.44(\mathrm{~s}, 2 \mathrm{H}), \quad 5.33(\mathrm{~s}, 2 \mathrm{H}), \quad 4.89(\mathrm{~s}, 2 \mathrm{H})$, 4.48(s,2H),4.21(s,5H); IR (KBr) v: 3428, 3111, 2924, 1702, 1461, 1271, $1131 \mathrm{~cm}^{-1}$; ESI-MS $\mathrm{m} / \mathrm{z}$ : $322[\mathrm{M}+\mathrm{H}]^{+}$; HRMS calcd for $\mathrm{C}_{17} \mathrm{H}_{15} \mathrm{O}_{2} \mathrm{~N}_{1} \mathrm{Fe} 322.0525$, found 322.0535 .

Ferrocene formyl oxygen radicals benzotriazole (Fc6)

Mp:135.9-137. ${ }^{\circ} \mathrm{C} ;{ }^{1} \mathrm{H} \operatorname{NMR}\left(\mathrm{CDCl}_{3}, 500 \mathrm{MHz}\right) \delta$ : $8.13(\mathrm{~d}, J=8.5 \mathrm{~Hz}, 1 \mathrm{H}), \quad 7.58(\mathrm{t}, J=7.5 \quad \mathrm{~Hz}, 1 \mathrm{H})$,
7.44-7.52(m,2H), 5.12(s,2H), 4.72(s,2H), 4.48(s,5H); IR (KBr) v: 3428, 3099, 2924, 2854, 1777, 1445, 1261, 1107, $749 \mathrm{~cm}^{-1}$; ESI-MS $\mathrm{m} / z$ : $348[\mathrm{M}+\mathrm{H}]^{+}$; HRMS calcd for $\mathrm{C}_{17} \mathrm{H}_{13} \mathrm{O}_{2} \mathrm{~N}_{3} \mathrm{Fe} 348.0435$, found 348.0449.

3-Ferrocene formyl propionic acid-4-methyl pyridine (Fc12)

Mp.79.5-81.0 $\quad{ }^{\circ} \mathrm{C} \quad ;{ }^{1} \mathrm{H} \quad \mathrm{NMR}\left(\mathrm{CDCl}_{3}, 500 \mathrm{MHz}\right)$ $\delta: 8.70(\mathrm{~s}, 2 \mathrm{H}), \quad 7.33(\mathrm{~s}, 2 \mathrm{H}), \quad 5.20(\mathrm{~s}, 2 \mathrm{H}), \quad 4.83(\mathrm{~s}, 2 \mathrm{H})$, $4.53(\mathrm{~s}, 2 \mathrm{H})$,

$3.13(\mathrm{t}, J=6.3 \mathrm{~Hz}, 2 \mathrm{H}), 2.82(\mathrm{t}, J=6.3 \mathrm{~Hz}, 2 \mathrm{H})$;

${ }^{4.25}(\mathrm{~s}, 5 \mathrm{H})$

$\mathrm{NMR}\left(\mathrm{CDCl}_{3}, 125 \mathrm{MHz}\right) \delta: 201.8,172.7,149.9,145.2$, 122.0, 78.3, 72.3, 70.2, 69.2, 64.5, 34.2, 27.9; IR (KBr) $v: 3434,3093,2929,1736,1667,1455,1278,1157$, $819 \mathrm{~cm}^{-1}$; ESI-MS m/z: $378[\mathrm{M}+\mathrm{H}]^{+}$; HRMS calcd for $\mathrm{C}_{20} \mathrm{H}_{19} \mathrm{O}_{3} \mathrm{~N}_{1} \mathrm{Fe}$ 378.0793, found 378.0810.

4-Ferrocene formyl butyric acid-4-methyl pyridine (Fc17)

Mp.82.8-83. ${ }^{\circ} \mathrm{C} ; 1 \mathrm{H}$ NMR(CDCl3, $\left.500 \mathrm{MHz}\right) \delta$ : $8.64(\mathrm{~s}, 2 \mathrm{H}), \quad 7.28(\mathrm{~s}, 2 \mathrm{H}), \quad 5.18(\mathrm{~s}, 2 \mathrm{H}), \quad 4.79(\mathrm{~s}, 2 \mathrm{H})$, $4.52(\mathrm{~s}, 2 \mathrm{H}), \quad 4.20(\mathrm{~s}, 5 \mathrm{H}), \quad 2.83(\mathrm{~s}, 2 \mathrm{H}), \quad 2.58(\mathrm{~s}, 2 \mathrm{H})$ $2.10(\mathrm{~s}, 2 \mathrm{H}) ;{ }^{13} \mathrm{C} \mathrm{NMR}(\mathrm{CDCl} 3,125 \mathrm{MHz}) \delta: 203.4$, $172.8,149.8,144.8,122.7,78.9,72.3,69.8,69.3,64.3$, $38.2,33.3,19.5$; IR (KBr) v: 3427, 3098, 2922, 1743, $1671,1456,1281,1172,796 \mathrm{~cm}^{-1}$; ESI-MS $\mathrm{m} / \mathrm{z}$ : $392[\mathrm{M}+\mathrm{H}]^{+}$; HRMS calcd for $\mathrm{C}_{21} \mathrm{H}_{21} \mathrm{O}_{3} \mathrm{~N} 1 \mathrm{Fe}$ 392.0949, found 392.0981.

\subsubsection{Synthesis of compounds Fc1-Fc4, Fc7-Fc11, Fc13-Fc16, and Fc18}

Ferrocene carboxylic acid (2 mmol), EDCl (412 mg, 2 mmol), and HOBt (270 mg, $2 \mathrm{mmol})$ were dissolved in dichloromethane $(30 \mathrm{ml})$ and then stirred for $45 \mathrm{~min}$ in ice water. Then, $1 \mathrm{~b}-4 \mathrm{~b}$ or $7 \mathrm{~b}(2.0 \mathrm{mmol}$ or 4.0 mmol) was added to the solution and the mixture was stirred for $24 \mathrm{~h}$. After the reaction completion, as monitored by thin-layer chromatography, the solution was washed with brine and extracted with dichloromethane. The organic phase was dried over anhydrous sodium sulfate, filtered, and concentrated in vacuo to obtain the crude product. The residue was purified by flash chromatography (silica gel and ethyl acetate/petroleum ether) to provide the target compounds.

\section{1-Ferrocene formyl benzotriazole (Fc1)}

Mp. 145.6-147.4 ${ }^{\circ} \mathrm{C} ;{ }^{1} \mathrm{H}$ NMR(CDCl $\left.3,500 \mathrm{MHz}\right) \delta$ : 8.42(d,J=8.0Hz, $1 \mathrm{H}), \quad 8.19(\mathrm{~d}, J=8.0 \mathrm{~Hz}, 1 \mathrm{H}), \quad 7.69$ $(\mathrm{t}, J=7.5 \mathrm{~Hz}, 1 \mathrm{H}), 7.55(\mathrm{t}, J=7.3 \mathrm{~Hz}, 1 \mathrm{H}), 5.58(\mathrm{~s}, 2 \mathrm{H}), 4.77$ $(\mathrm{s}, 2 \mathrm{H}), 4.28(\mathrm{~s}, 5 \mathrm{H})$; IR (KBr) v: 3428, 3105, 2923, $1685,1441,1356,1258,1002,949,822,752 \mathrm{~cm}^{-1}$. ESI-MS $m / z: 331[\mathrm{M}]^{+}$; HRMS calcd for $\mathrm{C}_{13} \mathrm{H}_{13} \mathrm{ON}_{3} \mathrm{Fe}$ 331.0403, found 331.0404 .

\section{1-Ferrocene formyl imidazole (Fc2)}

Mp. 118.5-120.0 ${ }^{\circ} \mathrm{C}\left(121-122^{\circ} \mathrm{C}\right) ; \mathrm{IR}(\mathrm{KBr}) v: 3118$, $2925,1680,1444,1381,1304,1200,1101,821$ $\mathrm{cm}^{-1}$;ESI-MS $m / z: 281[\mathrm{M}+\mathrm{H}]^{+}$; HRMS calcd for $\mathrm{C}_{14} \mathrm{H}_{12} \mathrm{ON}_{2} \mathrm{Fe} 281.0371$, found 281.0374 .

\section{1-Ferrocene formyl piperazine $(\mathrm{Fc} 3)$}

${ }^{1} \mathrm{H}-\mathrm{NMR}\left(\mathrm{CDCl}_{3}, 500 \mathrm{MHz}\right): 4.94(\mathrm{~s}, 2 \mathrm{H}), 4.57$ (s, 2H), 4.20 (s, 5H), $3.83(\mathrm{~s}, 4 \mathrm{H}), 3.01(\mathrm{~s}, 4 \mathrm{H}), 1.93$ (s, 
1H); IR (KBr) v: 3421, 3307, 2939, 2913, 1617, 1475 , 1271, 1121, $1024 \mathrm{~cm}^{-1}$; ESI-MS m/z: 299[M+H] ; HRMS calcd for $\mathrm{C}_{15} \mathrm{H}_{18} \mathrm{ON}_{2} \mathrm{Fe}$ 299.0849, found 299.0848 .

2-Ferrocene formyl amine pyridine (Fc4)

Mp.126.4-127.3 ${ }^{\circ} \mathrm{C}\left(126-128^{\circ} \mathrm{C}\right) ;{ }^{1} \mathrm{H}-\mathrm{NMR}\left(\mathrm{CDCl}_{3}\right.$, $500 \mathrm{MHz}): 8.12(\mathrm{~d}, J=8.5 \mathrm{~Hz}, 1 \mathrm{H}), 7.58(\mathrm{t}, J=7.5 \mathrm{~Hz}, 1 \mathrm{H})$, 7.43-7.53 (m,2H), $7.20(\mathrm{~s}, 1 \mathrm{H}), 5.12(\mathrm{~s}, 2 \mathrm{H}), 4.72$ $(\mathrm{s}, 2 \mathrm{H}), 4.48(\mathrm{~s}, 5 \mathrm{H})$; IR (KBr) v: 3392, 2924, 1660, $1441,1015,820,779 \mathrm{~cm}^{-1}$; ESI-MS $m / z: 307[\mathrm{M}+\mathrm{H}]^{+}$; HRMS calcd for $\mathrm{C}_{16} \mathrm{H}_{14} \mathrm{ON}_{2} \mathrm{Fe} 307.0534$, found 307.0536.

1-methyl-4-ferrocene formyl piperazine (Fc7)

Mp.89.3-90. $6^{\circ} \mathrm{C}\left(88-90^{\circ} \mathrm{C}\right)$; IR (KBr) v: 3423, 2939 ,

2810, 1604, 1473, 1275, 1143, $1003 \mathrm{~cm}-1$; ESI-MS $\mathrm{m} / \mathrm{z}: 313[\mathrm{M}+\mathrm{H}]^{+}$; HRMS calcd for $\mathrm{C}_{16} \mathrm{H}_{20} \mathrm{ON}_{2} \mathrm{Fe}$ 313.1003 , found 313.1004 .

2-Ferrocene acetamino pyridine $(\mathrm{Fc} 8)$

Mp.105.3 ${ }^{\circ} \mathrm{C}$ decompose.1H NMR $(500 \mathrm{MHz}$, $\mathrm{CDCl}) \quad: \quad 8.12-8.30(\mathrm{~m}, 3 \mathrm{H}), 7.70(\mathrm{t}, \mathrm{J}=7.5 \mathrm{~Hz}, 1 \mathrm{H})$, $7.03(\mathrm{t}, \mathrm{J}=6.0 \mathrm{~Hz}, 1 \mathrm{H}), 4.01-4.33(\mathrm{~m}, 9 \mathrm{H}), 3.53(\mathrm{~s}, 2 \mathrm{H})$ 13C NMR(CDCl3, $125 \mathrm{MHz}) \delta: 169.4,151.2,147.8$ $138.3,119.8,113.8,80.2,70.7,69.0,39.1,29.7$; IR (KBr) v: $3448,3283,2924,1694,1444,1104,821$, $785 \mathrm{~cm}-1$; ESI-MS m/z:321[M+H]+; HRMS calcd for C17H16ON2Fe 321.0685, found 321.0697.

1-[3-Ferrocene formyl propionyl] benzotriazole (Fc9)

Mp.140.0-142.8 ${ }^{\circ} \mathrm{C} .1 \mathrm{H}$ NMR (500 MHz, CDCl3) $8.31(\mathrm{~d}, \mathrm{~J}=8 \mathrm{~Hz}, 1 \mathrm{H}), \quad 8.15 \quad(\mathrm{~d}, \mathrm{~J}=8.5 \mathrm{~Hz}, 1 \mathrm{H}), 7.65$ $(\mathrm{t}, \mathrm{J}=7.5 \mathrm{~Hz}, 1 \mathrm{H}), \quad 7.52(\mathrm{t}, \mathrm{J}=7.5 \mathrm{~Hz}, 1 \mathrm{H}), \quad 4.88(\mathrm{~s}, 2 \mathrm{H})$, $4.56(\mathrm{~s}, 2 \mathrm{H}), \quad 4.33(\mathrm{~s}, 5 \mathrm{H}), \quad 3.83(\mathrm{t}, \mathrm{J}=5.0 \mathrm{~Hz}, 2 \mathrm{H})$, $3.40(\mathrm{t}, \mathrm{J}=5.0 \mathrm{~Hz}, 2 \mathrm{H}) ; 13 \mathrm{CNMR}(\mathrm{CDCl} 3,125 \mathrm{MHz}) \delta$ : 201.6, 171.9, 146.2, 131.2, 130.3, 126.1, 120.1, 114.5, 78.2, 72.4, 70.1, 69.3, 33.6, 29.4; IR (KBr) v: 3098, 2924, 1737, 1675, 1378, 1256, 970, $779 \mathrm{~cm}-1$; ESI-MS m/z: $388[\mathrm{M}+\mathrm{H}]+; \quad$ HRMS calcd for $\mathrm{C}_{20} \mathrm{H}_{17} \mathrm{O}_{2} \mathrm{~N}_{3} \mathrm{Fe} 388.0784$, found 388.0790 .

1-[3-ferrocene formyl propionyl] piperazine (Fc10) Mp.144.2-144.5 ${ }^{\circ} \mathrm{C} .{ }^{1} \mathrm{H}$ NMR $\left(500 \mathrm{MHz}, \mathrm{CDCl}_{3}\right)$ $4.85(\mathrm{~s}, 2 \mathrm{H}), 4.53(\mathrm{~s}, 2 \mathrm{H}), 4.27(\mathrm{~s}, 5 \mathrm{H}), 3.76(\mathrm{~s}, 2 \mathrm{H}), 3.71$ $(\mathrm{s}, 2 \mathrm{H}), 3.17(\mathrm{t}, J=6.5 \mathrm{~Hz}, 2 \mathrm{H}), 3.07(\mathrm{~s}, 2 \mathrm{H}), 2.99(\mathrm{~s}, 2 \mathrm{H})$, $2.72(\mathrm{t}, J=6.5 \mathrm{~Hz}, 2 \mathrm{H}), 1.83(\mathrm{~s}, 1 \mathrm{H}) ;{ }^{13} \mathrm{C} \mathrm{NMR}(\mathrm{CDCl} 3$, $125 \mathrm{MHz}) \delta: 203.2,170.5,78.7,72.2,69.9,69.3,42.6$, 34.6,29.7, 26.6; IR (KBr) v: 3421, 3201, 2920, 1734, $1664,1650,1422,1238,1050,789 \mathrm{~cm}^{-1}$; ESI-MS $\mathrm{m} / z$ : $355[\mathrm{M}+\mathrm{H}]^{+}$; HRMS calcd for $\mathrm{C}_{18} \mathrm{H}_{22} \mathrm{O}_{2} \mathrm{~N}_{2} \mathrm{Fe}$ 355.1109 , found 355.1122 .

2-[3-ferrocene formyl propionyl] aminopyridine (Fc11)

Mp. $176-178.9^{\circ} \mathrm{C} .{ }^{1} \mathrm{H}$ NMR $\left(500 \mathrm{MHz}, \mathrm{CDCl}_{3}\right)$ : $8.71 \quad(\mathrm{~s}, 1 \mathrm{H}), \quad 8.32 \quad(\mathrm{~d}, J=3.5 \mathrm{~Hz}, 1 \mathrm{H}), \quad 8.25$ $(\mathrm{d}, J=8.0 \mathrm{~Hz}, 1 \mathrm{H}), \quad 7.72 \quad(\mathrm{t}, J=7.5 \mathrm{~Hz}, 1 \mathrm{H}), \quad 7.05$ $(\mathrm{t}, J=5.5 \mathrm{~Hz}, 1 \mathrm{H}), 5.32(\mathrm{~s}, 1 \mathrm{H}), 4.86(\mathrm{~s}, 2 \mathrm{H}), 4.54(\mathrm{~s}, 2 \mathrm{H})$, $4.26(\mathrm{~s}, 5 \mathrm{H}), 3.23(\mathrm{t}, J=6.0 \mathrm{~Hz}, 2 \mathrm{H}), 2.83(\mathrm{t}, J=6.0 \mathrm{~Hz}, 2 \mathrm{H})$; ${ }^{13} \mathrm{C}$ NMR(CDCl3, $\left.125 \mathrm{MHz}\right) \delta: 202.8,171.2,151.8$, 147.7, 138.4, 119.6, 114.3, 78.4, 72.4, 70.0, 69.3, 34.5, 31.1; IR (KBr) $v: 3421,3251,2923,1667,1595,1434$, 1299, $786 \mathrm{~cm}^{-1}$; ESI-MS m/z: $363[\mathrm{M}+\mathrm{H}]^{+}$; HRMS calcd for $\mathrm{C}_{19} \mathrm{H}_{18} \mathrm{O}_{2} \mathrm{~N}_{2} \mathrm{Fe} 363.0796$, found 363.0801 . 1-methyl-4-[3-ferrocene formyl propionyl] piperazine (Fc13)

Mp.104.4-106.0 ${ }^{\circ} \mathrm{C} .{ }^{1} \mathrm{H}$ NMR (500 $\mathrm{MHz}, \mathrm{CDCl}_{3}$ ) $4.84(\mathrm{~s}, 2 \mathrm{H}), 4.50(\mathrm{~s}, 2 \mathrm{H}), 4.25(\mathrm{~s}, 5 \mathrm{H}), 3.67(\mathrm{~s}, 2 \mathrm{H}), 3.60$ $(\mathrm{t}, J=5.0 \mathrm{~Hz}, 2 \mathrm{H}), \quad 3.13 \quad(\mathrm{t}, J=6.5 \mathrm{~Hz}, 2 \mathrm{H}), \quad 2.71$ $(\mathrm{t}, J=7.0 \mathrm{~Hz}, 2 \mathrm{H}), \quad 2.46 \quad(\mathrm{t}, J=4.8 \mathrm{~Hz}, 2 \mathrm{H}), \quad 2.40$ $(\mathrm{t}, J=5.0 \mathrm{~Hz}, 2 \mathrm{H}), \quad 2.33(\mathrm{~s}, 3 \mathrm{H}) ;{ }^{13} \mathrm{CNMR}(\mathrm{CDCl} 3,125$ MHz) $\delta$ : 203.2, 170.3, 78.7, 72.2, 69.9, 69.3, 55.1, 54.7, $46.0,45.3,41.7,34.6,26.7$; IR (KBr) v: 3434, 3093 , $2930,1736,1667,1605,1455,1180,821 \mathrm{~cm}^{-1}$; ESI-MS $m / z: \quad 369[\mathrm{M}+\mathrm{H}]^{+}$; HRMS calcd for $\mathrm{C}_{19} \mathrm{H}_{24} \mathrm{O}_{2} \mathrm{~N}_{2} \mathrm{Fe} 369.1260$, found 369.1279.

1-[4-ferrocene formyl butyryl] benzotriazole (Fc14) Mp.119.7-121.8 $\quad{ }^{\circ} \mathrm{C} \quad{ }^{1} \mathrm{H} \quad \mathrm{NMR}(500 \quad \mathrm{MHz}$, $\left.\mathrm{CDCl}_{3}\right): 8.35(\mathrm{~d}, J=8.0 \mathrm{~Hz}, 1 \mathrm{H}), 8.16(\mathrm{~d}, J=8.0 \mathrm{~Hz}, 1 \mathrm{H})$, $7.70(\mathrm{t}, J=7.8 \mathrm{~Hz}, 1 \mathrm{H}), 7.54(\mathrm{t}, J=7.5 \mathrm{~Hz}, 1 \mathrm{H}), 4.84(\mathrm{~s}, 2 \mathrm{H})$, $4.54 \quad(\mathrm{~s}, 2 \mathrm{H}), \quad 4.24 \quad(\mathrm{~s}, 5 \mathrm{H}), \quad 3.61 \quad(\mathrm{t}, J=7.0 \mathrm{~Hz}, 2 \mathrm{H})$, $2.98(\mathrm{t}, J=7.0 \mathrm{~Hz}, 2 \mathrm{H}), \quad 2.36 \quad(\mathrm{t}, J=7.0 \mathrm{~Hz}, 2 \mathrm{H})$; ${ }^{13} \mathrm{CNMR}(\mathrm{CDCl} 3,125 \mathrm{MHz}) \delta: \quad 203.2, \quad 172.2, \quad 146.2$, $131.1,130.4,126.1,120.2,114.4,78.9,72.3,69.8$, 69.3, 38.3, 34.9, 29.7; IR (KBr): 3096, 2921, 1738 , $1663,1453,1390,1084,975,777 \mathrm{~cm}^{-1}$; ESI-MS $m / z$ : $401[\mathrm{M}]^{+}$; HRMS calcd for $\mathrm{C}_{21} \mathrm{H}_{19} \mathrm{O}_{2} \mathrm{~N}_{3} \mathrm{Fe} 401.0821$, found 401.0837 .

1-[4-ferrocene formyl butyryl] piperazine (Fc15)

Mp. $141^{\circ} \mathrm{C}$ decompose. ${ }^{1} \mathrm{H}$ NMR $\left(500 \mathrm{MHz}, \mathrm{CDCl}_{3}\right)$

: $7.62(\mathrm{~s}, 1 \mathrm{H}), 4.80(\mathrm{~s}, 2 \mathrm{H}), 4.52(\mathrm{~s}, 2 \mathrm{H}), 4.20(\mathrm{~s}, 5 \mathrm{H})$, $3.86(\mathrm{~d}, J=14.0 \mathrm{~Hz}, 4 \mathrm{H}), 3.16(\mathrm{~d}, J=14.0 \mathrm{~Hz}, 4 \mathrm{H}), 2.85$ $(\mathrm{t}, J=6.3 \mathrm{~Hz}, 2 \mathrm{H}), \quad 2.45 \quad(\mathrm{t}, J=6.8 \mathrm{~Hz}, 2 \mathrm{H}), \quad 2.03$ $(\mathrm{t}, J=6.5 \mathrm{~Hz}, 2 \mathrm{H}) ;{ }^{13} \mathrm{C} \mathrm{NMR}(\mathrm{CDCl} 3,125 \mathrm{MHz}) \delta: 203.7$ $171.1,79.5,72.5,70.0,69.5,41.3-39.1,38.6,32.0$, 20.1; IR (KBr) v: 3420, 3101, 2924, 1653, 1453, 1264 , $1090,828,750 \mathrm{~cm}^{-1}$; ESI-MS $\mathrm{m} / z: 369[\mathrm{M}+\mathrm{H}]^{+}$; HRMS calcd for $\mathrm{C}_{19} \mathrm{H}_{24} \mathrm{O}_{2} \mathrm{~N}_{2} \mathrm{Fe}$ 369.1266, found 369.1266 .

2-[4-ferrocene formyl butyryl] aminopyridine (Fc16)

Mp. $130^{\circ} \mathrm{C}$ decompose. ${ }^{1} \mathrm{H}$ NMR $\left(500 \mathrm{MHz}, \mathrm{CDCl}_{3}\right)$ $8.41 \quad(\mathrm{~s}, 1 \mathrm{H}), \quad 8.36-8.17 \quad(\mathrm{~m}, 2 \mathrm{H}), \quad 7.72$ $(\mathrm{t}, J=7.3 \mathrm{~Hz}, 1 \mathrm{H}), 7.05(\mathrm{~s}, 1 \mathrm{H}), 4.82(\mathrm{~s}, 2 \mathrm{H}), 4.21(\mathrm{~s}, 5 \mathrm{H})$, $2.88(\mathrm{~s}, 2 \mathrm{H}), 2.56(\mathrm{~s}, 2 \mathrm{H}), 2.2(\mathrm{~s}, 2 \mathrm{H}) ;{ }^{13} \mathrm{C} \mathrm{NMR}(\mathrm{CDCl} 3$, $125 \mathrm{MHz}) \delta$ : 203.8, 170.1, 150.3, 146.2, 137.0, 109.3, 93.3, 77.9, 71.6, 70.0, 68.6, 35.6, 32.1, 30.7; IR (KBr) $v: 3452,3255,2927,1690,1653,1525,1432,1296$ $824,780 \mathrm{~cm}^{-1}$; ESI-MS m/z: 377[M+H] $]^{+}$; HRMS calcd for $\mathrm{C}_{2} 2 \mathrm{H}_{20} \mathrm{O}_{2} \mathrm{~N}_{2} \mathrm{Fe} 377.0953$, found 377.0974.

1-methyl-4-[4-ferrocene formyl butyryl] piperazine (Fc18)

${ }^{1} \mathrm{H}$ NMR $\left(500 \mathrm{MHz}, \mathrm{CDCl}_{3}\right) \quad: 4.70(\mathrm{~s}, 2 \mathrm{H}), 4.40$ $(\mathrm{s}, 2 \mathrm{H}), 4.09(\mathrm{~s}, 5 \mathrm{H}), 3.44(\mathrm{~d}, J=7.0 \mathrm{~Hz}, 4 \mathrm{H}), 2.74(\mathrm{~s}, 2 \mathrm{H})$, $2.32 \quad(\mathrm{~s}, 6 \mathrm{H}), \quad 2.20 \quad(\mathrm{~s}, 3 \mathrm{H}), \quad 1.93 \quad(\mathrm{~s}, 2 \mathrm{H}) ;{ }^{13} \mathrm{C}$ NMR(CDCl3, $125 \mathrm{MHz}) \delta: 204.2,171.0,78.9,72.2$, 69.7, 69.2, 55.1, 54.6,45.9, 45.3, 41.3, 38.5, 32.4, 19.9; IR (KBr) $v: 3570,3103,2929,1671,1649,1454,1235$, $1001,825 \mathrm{~cm}^{-1}$; ESI-MS m/z: 383[M+H] $]^{+}$; HRMS calcd for $\mathrm{C}_{20} \mathrm{H}_{26} \mathrm{O}_{2} \mathrm{~N}_{2} \mathrm{Fe} 383.1448$, found 383.1439.

\subsection{Antiproliferative assays}

The antitumor activities of the target compounds on 
MCF-7 cells in vitro were tested by MTT assay. The cells were collected in the log phase. The concentration of the cell suspension was adjusted, and the cell suspension $(100 \mu \mathrm{L})$ was transferred to each well of a 96-well flat-bottom plate. The density of tested cells was adjusted to 1000-10 000 cells per well by decking (the wells on the edge were filled with sterile PBS). The cells were cultured at $37^{\circ} \mathrm{C}$ for $24 \mathrm{~h}$ in a $5 \% \mathrm{CO}_{2}$ incubator until a monolayer covered the bottom of the well. Subsequently, the cells were exposed to a concentration gradient of the different drugs, with 6 grads and $100 \mu \mathrm{L}$ per well. The cells were then cultured for $24 \mathrm{~h}$ in a $5 \% \mathrm{CO}_{2}$ incubator at $37{ }^{\circ} \mathrm{C}$ and observed with an inverted microscope. Subsequently, the supernatant was discarded and $20 \mu \mathrm{L}$ of MTT solution (5 $\mathrm{mg} / \mathrm{mL}$, that is, $0.5 \%$ MTT) was added to each well.

The cells were cultured for another $4 \mathrm{~h}$. Thereafter, the supernatant was discarded, $150 \mu \mathrm{L}$ DMSO was added to each well, and the cells were agitated for 10 min on a low-speed shaker until the crystals were fully dissolved. Finally, an automated multi-microplate reader was used to measure the absorbance of each well at 570 and $630 \mathrm{~nm}$.

\subsection{Docking simulations}

All docking calculations were carried out using Surflex-Dock (SYBYL-X2.0) in the docking mode of surflex-dock (SFXC). The X-ray structure of the AR crystal structure (PDB code 3EQM) was selected as the template for the modeling study and downloaded from the RCSB Protein Data Bank (http://www.rcsb.org/pdb/explore/explore.do?structure $\underline{\mathrm{Id}=3 \mathrm{EQM}}$ ). For ligand preparation, the ligand structure was generated and added with Gasteiger-Huckel charges, and the force field was tripos. At the same time, the energy minimization was needed for the process of dealing with ligand, so the maximum iterations were performed 1000 times and the gradient was set to $0.05 \mathrm{kcal} /(\mathrm{mol} \cdot \mathrm{A})$. For the protein preparation, the ligand ASD was extracted from the crystal structure. Then, all water existing in the protein, as well as in the ligand HEM and PO4, were removed. The selected structure was subsequently analyzed. The sidechain was repaired, the hydrogen atoms were added, and the type atoms were fixed. Then, terminus treatment was performed, the sidechain amides were added, and sidechain bumps were fixed. The final step was staged minimization, and then a pocket was produced as our active site.

\section{RESULTS AND DISCUSSION}

\subsection{Chemistry}

The synthesis route of ferrocene heterocyclic derivatives (Fc1 to Fc18) is outlined in Scheme 1[15]. As it is reported, the synthesis of compounds (Fc1-Fc18) was synthesized with the ferrocenyl carboxylic acid and different heterocycles with the help of $\mathrm{EDCl}$, HOBt, or DMAP in anhydrous methylene dichloride. All synthesized compounds Fc1-Fc18 (Figure 3) provided satisfactory elementary analytical and spectroscopic data. NMR, HR-MS, ESI-MS, and IR spectra were consistent with the assigned structures.

\subsection{Bioassay}

To test the anticancer activities of the synthesized compounds, we evaluated the representative compounds Fc1, Fc3, Fc9-Fc12, Fc14, and Fc17 in MCF-7 cells as summarized in Table 1. We observed that Fc3, Fc11, Fc12, and Fc17 displayed better inhibitory effect against MCF-7 cells than other four compounds. Their IC50 values were respectively 39.2, $44.2,48.3$, and $24.2(\mu \mathrm{mol} / \mathrm{L})$.

Based on the molecular structures, eight heterocyclic ferrocene derivatives that had a pyridine group and owned ester were more effective in inhibiting MCF-7 cells than that of ferrocene heterocyclic derivatives without a pyridine group and did not own amide. Eight heterocyclic ferrocene derivatives substituted with a pyridine group had better biological activity against MCF-7 cells than the compounds that lacked a pyridine group. Thus, introducing a pyridine group into ferrocene better improved the antitumor activity against MCF-7 cells of Fc11, Fc12, and Fc17. In addition, from the perspective of docking simulation, we try to find out the probable reasons why the compounds have antitumor activities.

\subsection{Molecular docking}

To clarify the binding mode of heterocyclic ferrocene derivatives with aromatase compared with exemestane (Aromasin; one of the three aromatase inhibitors approved by the US Food and Drug Administration), the 18 compounds Fc1-Fc18 molecules were docked into the active site of aromatase where the original ligand was removed. The crystal structure of the enzyme was obtained from the Protein Data Bank (PDB code 3EQM). According to the previous literature ${ }^{14}$ (Figure 3 ), the residues comprising the catalytic cleft are Ile 305, Ala 306, Asp 309 and Thr 310, Trp 224, Ile 133, Phe 134, Val 370, Leu 372, Val 373, Met 374, and Leu 477. The 2D interaction maps between the compounds and the $3 \mathrm{EQM}$ protein crystal structure are displayed in Figures 5A-5D, which can aid in elucidating the interaction forces. Examination of the crystal structure showed the existence of only one hydrogen bond consisting of residues Met374 and the N atom, which is involved in the binding between the compound and the active site (Figure 5A). The number of van der Waals displayed in Fc11 (Figure 5B) exceeded that in $\mathbf{F c 3}$, while the Met374 residues just played a role as van der Waals forces. Unfortunately, only one 
ICETA 2015

pink electrostatic interaction existed between Fc11 and Leu477. There is no one hydrogen bond existed. The Met374 residues also played a role but as van der Waals forces. 


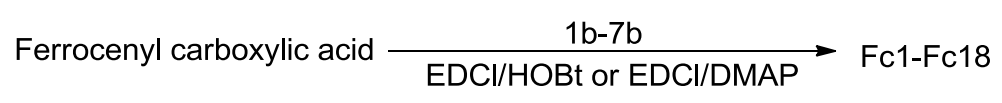

Ferrocenyl carboxylic acid $=$

1a FcCOOH ; $2 \mathrm{a} \mathrm{FcCH} 2 \mathrm{COOH} ; 3 \mathrm{a}-4 \mathrm{a} \mathrm{FcCO}\left(\mathrm{CH}_{2}\right)_{n} \mathrm{COOH} ; \mathrm{n}=2,3 ; \mathrm{Fc}=\mathrm{Fe}$

(b)<smiles>CN1CCNCC1[18O]n1nnc2ccccc21</smiles>

Figure 2. Synthesis of compounds Fc1 to Fc18. Reagents and conditions: (i) EDCl+HOBt or EDCl+DMAP; r.t.; $24 \mathrm{~h}$<smiles>[R]c1ccccc1-c1ccccc1</smiles>

Fc1<smiles>O=CN1CCNCC1</smiles>

Fc3<smiles>O=CNc1ccccn1</smiles>

Fc4<smiles>O=COCc1ccncc1</smiles>

Fc5<smiles>O=COn1nnc2ccccc21</smiles>

Fc6<smiles>CC(=O)Nc1ccccn1</smiles><smiles>CCCCCC(F)(F)C(F)(F)F</smiles>

Figure 3. Structures of compounds Fc1-Fc18

Table 1. Inhibition $\left(\mathrm{IC}_{50}\right)$ of MCF-7 cells by compounds Fc1, Fc3, Fc9-Fc12, Fc14, and Fc17 (inhibition ratio, \%)

\begin{tabular}{lllllllll}
\hline \multirow{2}{*}{$\begin{array}{l}\text { Com- } \\
\text { pounds }\end{array}$} & $\begin{array}{l}\mathrm{IC}_{50} \\
(\mu \mathrm{mol} / \mathrm{L})\end{array}$ & \multicolumn{7}{c}{ Concentration $(\mu \mathrm{mol} / \mathrm{L})$} \\
\cline { 3 - 8 } Fc1 & 49.2 & 0 & 6.25 & 12.5 & 25 & 50 & 100 & 200 \\
\hline Fc3 & 39.2 & 0 & 4.8 & 27.4 & 43.5 & 60.3 & 60.7 & 64.6 \\
Fc9 & - & 0 & 6.4 & 17.8 & 38.2 & 40.0 & 41.8 & 44.1 \\
Fc10 & 171 & 0 & 0.8 & 15.8 & 37.7 & 44.0 & 42.0 & 55.6 \\
Fc11 & 44.2 & 0 & 40.2 & 45.8 & 46.7 & 52.9 & 54.2 & 57.1 \\
Fc12 & 48.3 & 0 & 46.0 & 49.0 & 49.5 & 51.7 & 53.5 & 67.1 \\
Fc14 & 97.6 & 0 & 27.9 & 48.2 & 44.6 & 48.4 & 50.9 & 68.0 \\
Fc17 & 24.2 & 0 & 35.8 & 46.9 & 50.6 & 51.8 & 53.9 & 55.1 \\
\hline
\end{tabular}


ICETA 2015

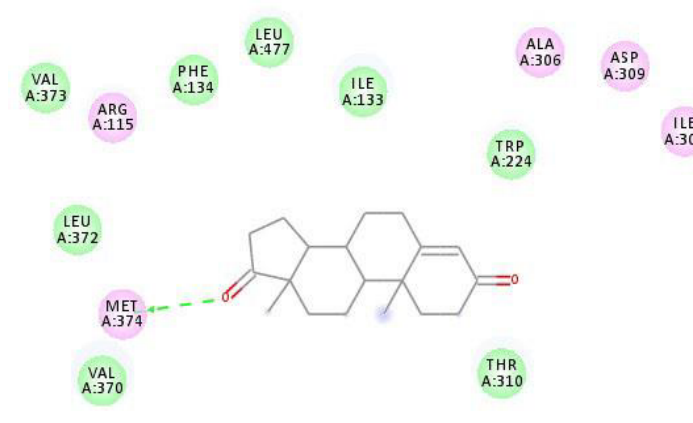

Figure 4. 2D molecular docking model of exemestane ${ }^{14}$ with 3EQM.

The results were calculated by Surflex-Dock, and the pictures were made by Discovery studio 3.5.

Unfortunately, only one pink electrostatic interaction existed between Fc11 and Leu477. The binding mode of Fc12 interaction with the enzyme protein is presented in Figure 5C. Docking results revealed that one hydrogen bond between the $\mathrm{N}$ atom from $\mathbf{F c 1 2}$ with the Ser314 residues. Meanwhile, Pro429, Cys437, and Phe430 that located in the binding pocket of the protein played an electrostatic role in the interaction of Fc12, as well as in the interaction of Met374, Met364, Leu477, and so on. They are with Fc12 by van der Waals forces.

At last, Fc17 had two hydrogen bonds involving the $\mathrm{O}$ and $\mathrm{N}$ atoms from the compound and the residues Thr310 and Ser314 respectively (Figure 5D). Except for the two hydrogen bonds, the electrostatic interaction between Fc12 and Cys437 can be also clearly seen in Fc17 around the active site. According to the 2D interaction maps, Fc17 may be surrounded by 20 residues such as Met447 and Leu477. Therefore, we anticipated that Fc17 could embed well into the active pocket and may have considerably better physicochemical properties than other ferrocene heterocyclic derivatives. Furthermore, the enzyme surface model (Figure 5) revealed that $\mathbf{F c 1 7}$ occupied the active pocket and was bound to an active conformation of AR. Therefore, we inferred the probable reason for the Fc17 had better antitumor activities than other compounds in the eight representative compounds. 


\section{MATEC Web of Conferences}

\section{CONCLUSION}

A series of ferrocene heterocyclic derivatives (Fc1Fc18) was synthesized, and eight of them were evaluated for their antitumor activities and found to exhibit antitumor activity against MCF-7 cells. Among the eight compounds, Fc3, Fc11, Fc12, and Fc17 demonstrated more anticancer activities against MCF-7 cells $\left[\mathrm{IC}_{50}\right.$ values are respectively $39.2,44.2,48.3$, and 24.2 $(\mu \mathrm{mol} / \mathrm{L})$,$] . Docking simulation studies were per-$ formed to position Fc17 in the human aromatase ac- tive site to explain the probable reasons why the compounds have antitumor activities. Analysis of the binding conformation of $\mathbf{F c 1 7}$ in the active site of the enzyme demonstrated that Fc17 had two hydrogen bonds which are composed of $\mathrm{O}$ and $\mathrm{N}$ atoms from the compound and residues Thr310 and Ser314. The results of our study can contribute to the design and synthesis of a leading compound, Fc17, for the development of new therapeutic agents against human breast cancer.
(A)

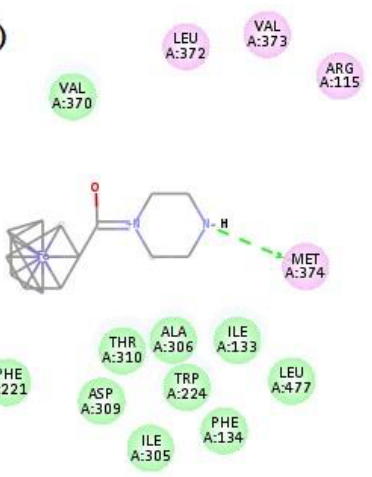

(C)
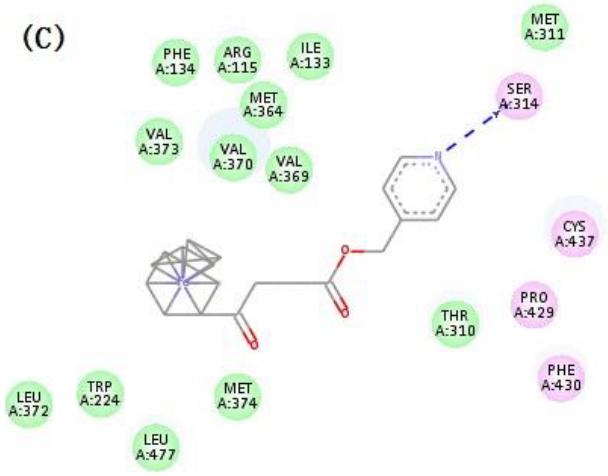

(B)
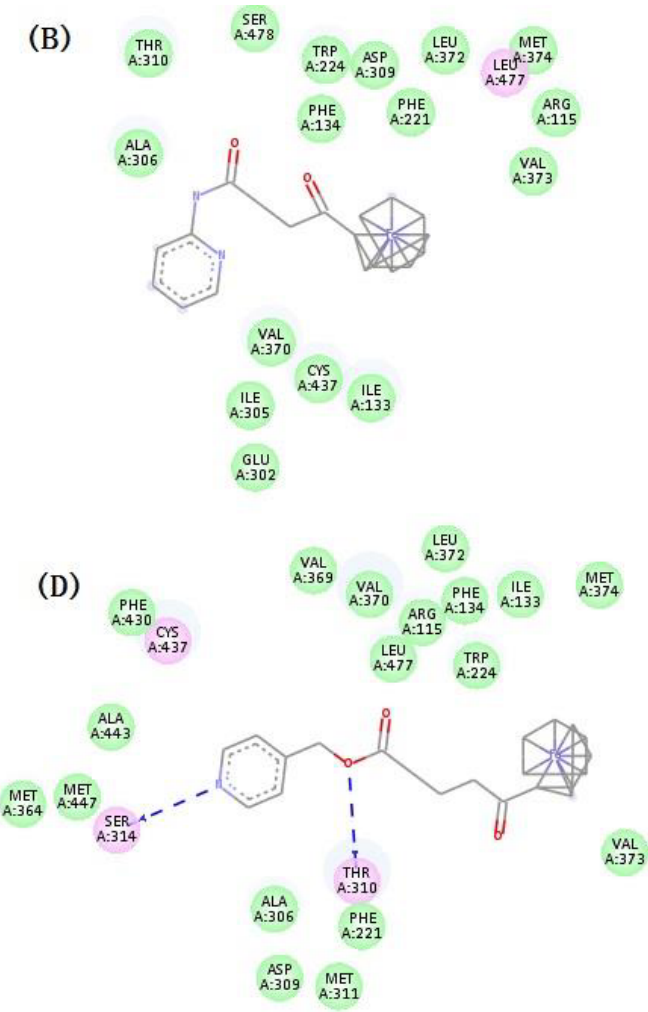

Figure 5 A). 2D molecular docking model of compound Fc3 with 3EQM. The results were calculated by Surflex-Dock, and the pictures were made by Discovery studio 3.5. B) 2D molecular docking model of Fc11 with 3EQM. C) 2D molecular docking model of Fc12 with 3EQM. D) 2D molecular docking model of Fc17 with 3EQM (electrostatic, pink; van der Waals, green; and the H-bonds are represented by a dashed line). 

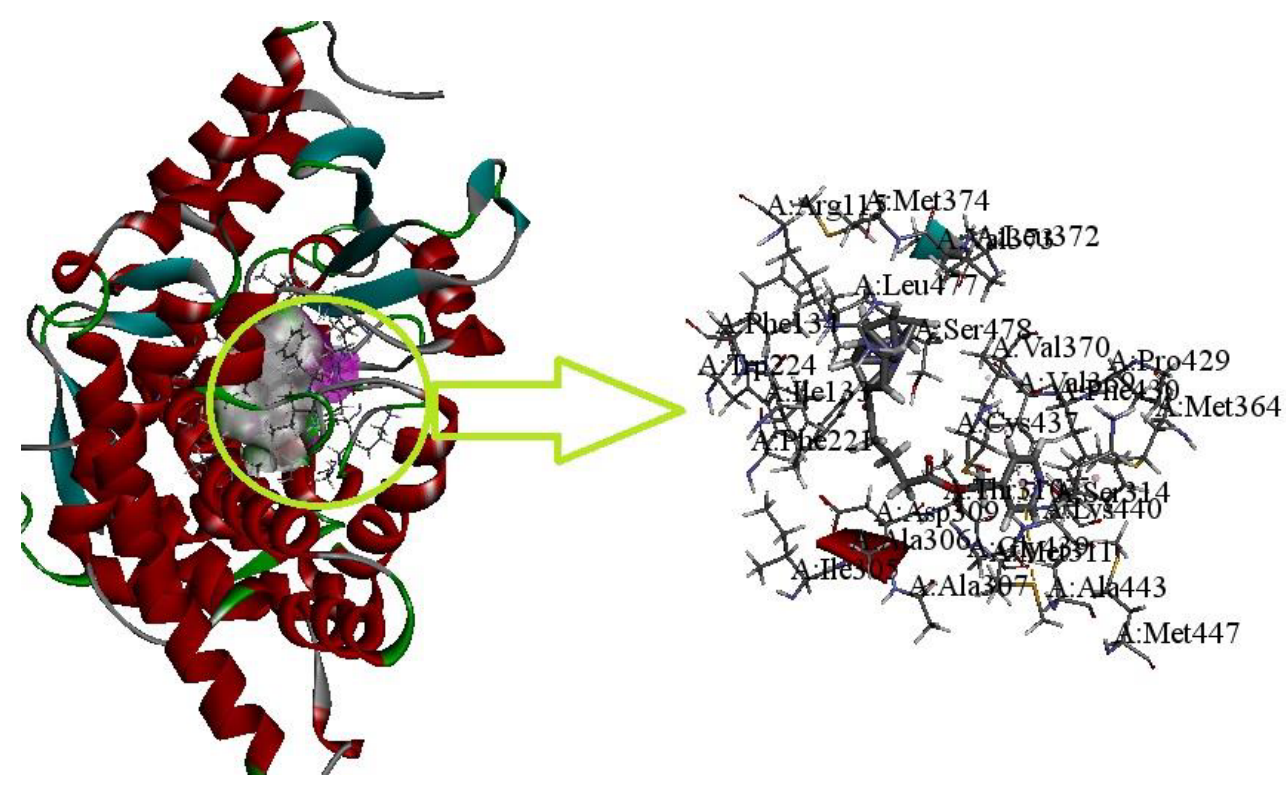

Figure 6. Docking result of the compounds in the study. The binding site (3EQM) surrounding the compound Fc17, the view of the pocket and the surfaces was transparent and presented by electrostatic potential, the secondary structure of the protein is displayed by an opaque ribbon. Hydrogen bonds are shown as yellow dashed lines. The inhibitor is also shown as a gray stick model.

\section{REFERENCES}

[1] Pauson P L. 1954. Ferrocene Derivatives. Part I. The direct synthesis of substituted ferrocenes. J. Am. Chem. Soc. 76(8): 2187-2191.

[2] Kealy T J. \& Pauson P L. 1951. A new type of organo-iron compound. Nature.168: 1039.

[3] Yuan.Y.F. \& Ye.S.M. 1995. Ferrocene derivatives with biological (Richard) activity .Chemistry; 5: 24-31.

[4] Babin VN, Dubinin AV, Raevskii PM, Sviridov AF. \& Sherman AL. 1979. Model' khimicheskogo carcinogeneza (molekulyarnye aspekty). Modeli. Algoritmy. Prinyatie Reshenii. Nauka: Moscow, 153-167.

[5] Popova (Snegur) LV, Babin VN, Belousov YuA, Nekrasov YuS, Snegireva AE, Borodina NP, Shaposhnikova GM, Bychenko OB,Raevskii PM, Morozova NM,Ilyina AI,Shitkov KG. 1993. Antitumor effects of binuclear ferrocene derivatives. Appl. Organometal. Chem. 7: 85.

[6] Kopf-Maier P, Kopf H. \& Neuse EW. 1984. Ferrocenium Salts-The First Antineoplastic Iron Compounds. Angew. Chem. 96: 446.

[7] Lubov V. Snegur, Yury S. Nekrasov, Nataliya S. Sergeeva, Zhanna V. Zhilina, Vera V Gumenyuk, Zoya A. Starikova, Alexander A. Simenel, Nataliya B. Morozova, Irina K. Sviridova \& Valery N. Babin. 2008. Ferrocenylalkyl azoles: Bioactivity, synthesis, structure. Appl. Organometal. Chem. 22: 139-147.

[8] Amir, E.; Freedman, O. C.; Seruga, B. \& Evans, D. G. 2010. Assessing women at high risk of breast cancer: a review of risk assessment models. J. Natl. Cancer Inst. 102: 680-691.

[9] Grodin, J. M.; Siiteri, P. K. \& MacDonald, P. C. 1973. Source of estrogen production in postmenopausal women. J. Clin. Endocrinol. Metab. 36: 207-214.

[10]O'Neill, J. S.; Elton, R. A. \& Miller, W. R. 1988. Aromatase activity in adipose tissue from breast quadrants: a link with tumour site. Br. Med. J (Clin. Res. Ed.). 296: 741-743.

[11] Brueggemeier, R. W. 2006. Update on the use of aromatase inhibitors in breast cancer. Expert Opin. Pharmacother. 7: 1919-1930.

[12] Brueggemeier, R. W; Hackett, J. C. \& Diaz-Cruz, E. S. 2005. Aromatase inhibitors in the treatment of breast cancer. Endocr. Rev. 26: 331-345.

[13]Debashis Ghosh, Jessica Lo, Daniel Morton,Damien Valette, Jingle Xi, Jennifer Griswold, Susan Hubbell, Chinaza Egbuta, Wenhua Jiang, Jing An, \& Huw M. L. Davies. 2012. Novel aromatase inhibitors by structure-guided design. J. Med. Chem. 55: 8464-8476.

[14] Ghosh, D.; Griswold, J.; Erman, M. \& Pangborn, W. 2009. Structural basis for androgen specificity and oestrogen synthesis in human aromatase. Nature. 457, 219-223.

[15] Gong X, Yang X. \& Wang D X. 2006. A new route for the synthesis of N-substituted diketopiperazine derivatives. Chin. Chem. Lett. 17(4): 469-472.

[16]Xiao Q, Jiu Feng Z, Hong Li Z. \& Min Bo L. 2009. Synthesis and mechanism research of two kinds of ferrocene carboxylic acid based on Willgerodt-Kindler reaction. Chin. Organic. Chemistry. 29(5): 748-752. 
MATEC Web of Conferences

[17] Kenneth L, Rinehart J R, Cursu, J R. \& Phillip E S

1957. Organic chemistry of ferrocene. II. the preparation

of ferrocenyl aliphatic. J. Am. Chem. Soc. 79(13):

3420-3424 